Western University

Scholarship@Western

Centre for the Study of International Economic

Centre for the Study of International Economic

Relations Working Papers

Relations

1989

\title{
An Empirical Database for a General Equilibrium Model of the European Communities
}

Glenn W. Harrison

Thomas F. Rutherford

Ian Wooton

Follow this and additional works at: https://ir.lib.uwo.ca/economicscsier_wp

Part of the Economics Commons

Citation of this paper:

Harrison, Glenn W., Thomas F. Rutherford, Ian Wooton. "An Empirical Database for a General Equilibrium Model of the European Communities." Centre for the Study of International Economic Relations Working Papers, 8901C. London, ON: Department of Economics, University of Western Ontario (1989). 
ISSN $0228-4235$

ISBN $0-7714-1072-7$

THE CENTRE FOR THE STUDY OF INTERNATIONAL ECONOMIC RELATIONS

WORKING PAPER NO. 8901C

\title{
AN EMPIRICAL DATABASE FOR A GENERAL EQUILIBRIUM MODEL OF THE EUROPEAN COMMUNITIES
}

\author{
Glenn W. Harrison \\ Thomas F. Rutherford \\ Ian Wooton
}

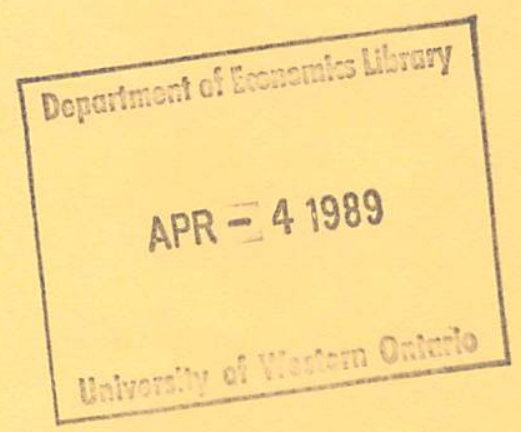

This paper contains preliminary findings from research work still in progress and should not be quoted without prior approval of the authors.

DEPARTMENT OF ECONOMICS

THE UNIVERSITY OF WESTERN ONTARIO

LONDON • CANADA

N6A 5 C2 


\title{
An Empirical Database for A General Equilibrium Model of The European Communities
}

by

Glenn W. Harrison, Thomas F. Rutherford, and Ian Wooton ${ }^{*}$

January 1989

Correspondence to:

\author{
Glenn W. Harrison \\ Department of Economics \\ University of New Mexico \\ Albuquerque, NM 87131 \\ U.S.A. \\ Bitnet: HARRISON@UNMB
}

*University of New Mexico, University of Western Ontario, and University of Western Ontario, respectively. 


\section{INTRODUCTION}

This paper documents the main features of an empirical database that has been constructed for use in an applied general equilibrium (GE) model. The model is primarily designed to evaluate the effects on welfare and resource allocation of the accession of countries to the European Community (EC). Recent historical accessions include the U.K., Denmark and Ireland in the mid-1970's, Greece in the early 1980's and Spain and Portugal in the mid-1980's. The question of accession is currently being evaluated and debated in several other countries.

Our basic database explicitly includes each of the major members of the EC in the 1970's: Germany, France, Italy, the Netherlands, Belgium, the United Kingdom (UK), Denmark, and Ireland. We only exclude Luxembourg, as data are not readily available and the country is, in economic terms, too small to be of significance. Our database also includes three further trading regions: the United States (US), Japan, and a residual Rest Of World (ROW).

Three aspects of our database are documented. The first, in Section 2, is the collection and use of "raw data" from a number of sources for 1975. The second aspect, in Section 3, concerns generation of a multi-year database, with 1975 serving as a "reference year" for temporal updates to more recent years. The final aspect concerns application of the database in the calibration of a "generic" general-equilibrium trade model.

All of these features of our database will be of interest to readers of our simulations of the accession of the 1970's [see Harrison, Rutherford, and Wooton (1989a)], and the effects of the Common Agricultural Policy [see Harrison, Rutherford, and Wooton (1989b)]. The second and third aspects will also be of independent methodological interest to applied general equilibrium modellers. 


\section{ASSEMBLING THE RAW DATA}

We employed six major sources of data for 1975. The first is the series of InputOutput (IO) tables collected by the Statistical Office of the European Communities (various issues) for each of our eight EC members. These data provided extensive information for each of 44 production sectors on production, value added, final demand, taxes, and trade flows. The second source is the aggregate Direction of Trade (DOT) data collection by the International Monetary Fund (various issues). This provides annual information on the value of total imports and total exports between every pair of countries we consider. The third source is the IO tables for the US and Japan collected by the Institute of Developing Economies (1982c).

The fourth source is the detailed annual breakdown of expenditures under the Common Agricultural Policy (CAP) in the annual "Agricultural Situation" report of the European Commission (1987). The fifth source is the "exchange rate conversion factors" and real GDP data of the International Comparisons Project (ICP) documented in Summers and Heston (1988). The final source is the time series of "Balance of Payments" data collected by the World Bank (1988). A large number of auxiliary sources of data have also been employed for selected areas, as indicated below.

\subsection{The Raw Data}

The basic source of data is the Statistical Office of the European Communities (1983) publication of 1975 input-output tables for each of Germany, France, Italy, the Netherlands, Belgium, the UK, Ireland, and Denmark. Tables for Luxembourg were not available and so, taking into account its relatively small size, the country is ignored. These tables are consolidated, in the sense that they have been prepared, as far as possible, on a consistent valuation basis (especially vis $a$ vis the treatment of VAT) and with identical sectoral coverage. These data are one part of the European System of Integrated Economic Accounts (ESA) maintained by the Statistical Office of the European Communities (also known as Eurostat). This greatly facilitates our task of constructing a multi-country model. 
Table 1 lists the 44 "branches and sub-branches" at which the basic data have been assembled. We refer to these as "sectors", to be consistent with our usage in the text. The raw data have been assembled at this level of disaggregation, even though we typically employ an aggregated version in our GE model. This is to facilitate later uses of the model in which it may be desirable to maintain a higher level of disaggregation in certain sectors. For example, our model of the CAP keeps the disaggregation of Agriculture, while aggregating more heavily in Manufacturing.

Table 2 lists the 12 categories of "final uses" that are available. An asterisk indicates which of these categories we have employed in the data set. Table 3 lists the 28 categories of "primary inputs" that have been incorporated.

Table 4 displays the structure of the raw data file for each country. The structure is identical for each country, although this does involve certain synthetic data for the case of France and Ireland (discussed later) due to the unavailability of the raw data for certain items. All elements of each file are represented in millions of local currency. We eventually convert these data to billions of US dollar equivalent, employing "conversion factors" described later.

In each data file we have data on domestic and imported intermediate outlays and inputs. We decided against entering the full matrix of intermediates for each country, although such data are available. Instead we use the EEC8 aggregation provided by the Statistical Office of the European Communities (1983; pp.153-165) for domestic intermediate transactions and (separately) for imported intermediate transactions as the basis of a RAS procedure for each country using the control totals provided in the individual country tables.

Data are also provided on final demand for the production of each sector in each country by domestic households (domestic consumers and government), the rest of the EC, and the rest of the non-EC world. Similar data are provided on domestic final demand for imported production. The primary inputs data provide details on value added (payments to Labour and Capital, especially) and taxes and tariffs paid to government. Note that imports and tax and tariff payments are distinguished by EC or non-EC source. 
In addition to the above data, which have been assembled for each of the EEC countries listed earlier, we employ further data on the EC or non-EC source of imported intermediates. These data were available in the individual IO tables constructed by the Statistical Office of the European Communities (1981a, 1981b, 1981c, 1981d, 1982a, 1982b, 1982c). These individual tables also disaggregate, by EC and non-EC, the source of imports for final consumption by domestic households and total final demand.

\subsection{Modifications and Extensions}

A number of modifications and extensions to the basic database have been made. Each of these is now described.

\section{Adjustments to the French Data}

The French data do not include a breakdown of sectoral value-added into payments to Labour and Capital (as we interpret the value added components list). We therefore employ the fraction of sectoral value added going to each item from the German data, and ratio off the desired values for France using the French total value added data. Thus the primary factor intensities of the French production sectors will actually reflect the German factor intensities. This problem could presumably be overcome by examining the primary sources of the French IO table.

\section{Adjustments to the Irish Data}

The Irish data do not distinguish between domestic and imported sources of transactions, but instead aggregate the two. We therefore construct such data by using the ratio of each transaction that is domestically sourced in the Netherlands, and using this ratio to construct the corresponding Irish component.

\section{$\underline{\mathrm{Re}-\text { Classifying Agricultural Factor Payments }}$}

A common problem in GE models of agriculture is the treatment of factor payments to owner-occupiers for the supply of their Labour and implicit payments for the supply of Land. Each of these payments typically appears as gross operating surplus in IO accounts. When this 
surplus is defined to be payments to (working) Capital, the implied Capital-Labour ratio in agriculture can be extremely high. For our database, this ratio ranges from 1.9 (for the UK) to 19.2 (for Belgium) among EC members. Most countries are in the range of 4 to 5 .

Our approach to this problem is to re-classify implied payments to Capital in agriculture into two components: (i) imputed payments for the Labour supply of owneroccupiers, and (ii) imputed payments to Land. The first of these is added to existing payments to Labour. The second defines payments to a factor that is specific to agriculture.

In the absence of any data for the EC, we employed the re-classification shares derived by Vincent (1977) for a 1968/69 Australian database. Aggregating over the six agricultural sectors he identifies, we obtain a share of 0.335 for imputed Labour payments, 0.355 for imputed Land payments, and a (residual) share of 0.310 remaining as payments to Capital.

\section{Data on the Common Agricultural Policy .}

The Common Agricultural Policy (CAP) of the EC represents the major item of budgetary expenditure of the EC, and is by far the most controversial of EC policies. We therefore take particular care when calibrating expenditures incurred under the CAP. Our basic source is the annual "Breakdown of appropriation by sector according to the economic nature of the measures" reported in The Agricultural Situation in the Community by the Commission of the European Communities. This annual report lists actual expenditures in the previous financial year and budgeted expenditures in the current year; we use the "actual" expenditure data.

Expenditures are listed by sector. We directly allocate expenditures for Beef and Veal, Pigmeat, Sheepmeat, and Eggs and Poultrymeat to our sector 16 (see Table 1), Milk and Milk Products to our sector 17, Wine to our sector 19, and Tobacco to our sector 20. The remaining expenditures are allocated to our sectors 1 and 18 on the basis of export or production shares. Thus if sector 18 had $90 \%$ of the (value of) exports of the two, it would have $90 \%$ of the unallocated Export Refunds of the CAP attributed to it. All other unallocated CAP 
expenditures were allocated to these two sectors on the basis of the value of production. The expenditures under the CAP are broken down by the EC into five types: (i) Export Refunds, (ii) Storage proper, (iii) Withdrawals from the market and similar operations, (iv) Price subsidies, and (v) Guidance premiums. Total CAP expenditures also include "Accession and Monetary Compensatory Amounts", so these are allocated to our sectors 1 and 18 as indicated above.

Non-Tariff Barriers

We employ "ad valorem equivalent" representation of non-tariff barriers (NTBs), using estimates for the EC, US, and Japan compiled by Whalley (1985; pp. 288-89) from Yeats $(1976,1979)$ and Roningen and Yeats (1976). These estimates refer to 33 sectors as defined in Whalley (1985; Table 3.4, pp. 68-69). It is a straightforward matter to match these to the sectors we employ here [see Tables 1 and 8]. We then aggregate these rates using benchmark import flows. The resulting NTBs are treated as if there were ad valorem tariffs.

\section{Elasticities}

For the existing model specification we require that several sets of elasticities be specified. In each case we employ CES functional forms, implying that we are solely interested in the relevant elasticity of substitution.

The first set is the elasticity of primary factor substitution. We employ the estimates generated by Harrison, Jones, Kimbell, and Wigle (1987; Appendix B, Table B3) and listed in Table 5. These estimates were generated from US time series data, typically from 1947 to 1982. They were estimated assuming a single-level CES production function between Capital and Labour. We also report standard errors on these estimates, in the event that sensitivity analysis is undertaken later. We aggregate these elasticities, when necessary, using value added as weights. 
The second set is the elasticity of substitution between imports from one source as against another source. Lacking any data on this elasticity, but presuming it to be relatively "high", we assume values of two for all sectors.

The third set is the elasticity of substitution between domestic and imported goods (the "Armington elasticity"). Table 6 reports the elasticities used here. We employ sector-specific values of the elasticity drawn from the Australian database presented in Dixon, Parmenter, Sutton, and Vincent (1982; pp.185-188). Using benchmark gross imports as weights, these values imply a country-specific average elasticity (it is country-specific since the import weights are country-specific). This average is then compared to the country-specific elasticity shown also in Table 8. These elasticities are taken from the literature review of own-price import elasticities reported in Harrison, Jones, Kimbell, and Wigle (1987; Appendix A, Tables $\mathrm{A} 2$ and A3); the ROW is proxied by the US literature-based estimate. We adopt the convention of assuming that the elasticity of substitution can be approximated by the negative of the uncompensated own-price elasticity [see Piggott and Whalley (1985; pp.163-167)]. We finally re-scale the sector-specific elasticities on a country-specific basis so that the implied (import-weighted) elasticity for each country is equal to the country-specific elasticities reported in Table 6. As a result of this process we obtain elasticities that are sector-specific and country-specific.

\section{Conversion Factors and Exchange Rates}

For the purpose of constructing our database we employ the US dollar as our common currency. With data from individual countries presented in terms of national currencies, we must adopt a series of "conversion factors". For a multitude of reasons, well-explained in Kravis, Heston, Kenessy, and Summers (1975), we choose not to employ official exchange rates. Those rates need not accurately reflect the "purchasing power" of the local currency over GDP relative to the US dollar. Instead we employ the Purchasing Power Parity (PPP) 
conversion factors developed by Summers and Heston (1988). Table 7 lists the 1975 values of these conversion factors and compares them to the (average) exchange rates for that year.

For the purpose of generating a database for a given year that allows comparisons of real GDP (and real sectoral production) it is sufficient to employ PPP conversion factors as indicated above. However, anticipating that we will be updating the database to other years (see Section 3) we also want to adopt a consistent value of GDP in the reference year, 1975. Therefore we scale the value of production in each country in 1975 to correspond to the real GDP values reported for 1975 (in 1980 prices) by Summers and Heston (1988). We preserve the sectoral shares of total output that we find in the raw data.

\section{Data for US and Japan}

The 1975 data for the US and Japan is drawn largely from the database employed in the Pacific Basin GE model of Harrison (1986). The primary sources for IO transactions (for domestic and foreign sourced inputs) and sectoral value added was the Institute of Developing Economies (1982c). This database is well documented by Higgs (1985), who also notes and corrects several inconsistencies in the original data. Data on the share of sectoral trade of the US and Japan with the EC (the EC12) for 1985 is obtained from the General Agreement on Tariffs and Trade (1987; Appendix A).

Table 8 lists the 24 production sectors in the Pacific Basin database. Far greater sectoral detail is available in the companion publications of the Institute of Developing Economies (1980, 1981a, 1981b, 1981c, 1982a, 1982b, 1982c). Some care must obviously be taken when aggregating sectors in the EC and Pacific Basin databases (cf. Tables 1 and 8) to ensure comparability.

\section{EC Budget}

The EC, as a supranational institution, generates large revenues and expenditures. Given the "open-ended" nature of some of the implicit financial commitments that the EC makes under the CAP, it is important to identify the sources and sinks of the EC budget. 
Table 9 shows the sources of revenues. The growing importance of VAT contributions in recent years is evident.

Tables 10 and 11 show the geographic share of revenues and expenditures for selected years. The microconsistent database requires that we specify the proportion of the EC budget that is "paid for" and "paid to" each EC member. For those years in which the available data do not provide that information (for example, Table 10 reports data for 1973-1975, but Table 11 does not) we employ the average shares reported in each table. Although individual gross shares do show some fluctuation from year to year, the basic pattern of net budgetary contributions remains quite stable. Germany is a heavy net contributor to the EC budget, with France and the UK being smaller net contributors. Denmark and Ireland are relatively heavy net recipients, with Italy a smaller net recipient.

\section{UPDATING THE RAW DATA}

A common difficulty with the construction of an empirical database for applied GE models is the antiquity of the reference year relative to "the present". This is obviously a difficulty when one is using the model to evaluate the effects of current policy proposals. Simulation results are easily attacked and discredited in the eyes of policy-makers because the model is deemed to be "out of date".

Two responses to this criticism are generally offered. The first is that it is rarely the scale of the economy so much as the structure of the economy that matters for GE model results. Thus, it is argued, unless there is some strong "a priori" reason to believe that the structure of an economy has changed, there is no reason to doubt the validity of the model. Needless to say, these arguments are not often evaluated empirically, it being claimed that domestic input-output coefficients do not change much over time and that sectoral and geographic trade shares do. 
The second response to the criticism is that the task of generating a consistent database for one year is large enough without having to do the same for a number of years. Moreover, there are invariably binding constraints on the availability of data for sufficiently recent years.

Our response is to use our benchmark year of 1975 as a "reference year" for the purpose of updating the database. Even if we had access to the same range and extent of data for other years, which we do not, it would still be a large task to re-assemble these data (unless it were all in machine-readable form). We therefore opt for using auxiliary data to "scale up" the structural features of our 1975 database to more recent years.

Specifically, we have annual data for each country and for the following variables: (i) GDP and gross trade flows, in current and constant (1980) units of local currency; (ii) conversion factors for purchasing power of local currency over GDP and its major components (consumption, domestic investment, and government expenditures) to US dollars; (iii) direction of gross imports and gross exports; (iv) excess contributions to the EC budget; (v) net foreign investment; and (vi) CAP expenditures, by product and nature of expenditure. These data are obtained from the World Tables of the World Bank (1983) as updated and compiled by the World Bank (1988) and Rutherford (1988a) [items (i) and (v)], Summers and Heston (1988) [items (i) and (ii)], the Direction of Trade Annual published by the International Monetary Fund [item (iii)], the European Commission Annual Reports [item (iv)], and the European Commission Agricutural Situation Reports [item (vi)].

We anticipate that annual data could also be obtained on the direction of sectoral trade from the United Nations; this would be a valuable extension of item (iii), given some presumption that sectoral trade shares may be quite volatile over several years. We also would expect to be able to obtain annual data on the aggregate shares of GDP attributable to Labour and Capital. We may be able to employ certain data on aggregate tax and tariff revenues, subsidy payments, and transfers from the Government Financial Statistics Annual of the IMF; unfortunately we have been unable to satisfactorily reconcile these data with our own data for 1975, implying that it would be unwise to suddenly use their data for other years. 
Finally, it would be possible to update annually the aggregate values of virtually all of our ESA data via the CRONOS database maintained by Eurostat on the network EURONET; that network and database are not available to us at this stage.

Items (iii), (iv), and (v) are employed directly to update their counterparts in the 1975 reference-year database. The only adjustment we make is to convert all expenditures in "local currency units in current dollars" into "US dollars in constant 1980 dollars" using the GDP conversion factors. This ensures that our databases for different years are comparable in real terms.

The series of real GDP values is used to "scale up" our 1975 transactions pertaining to value added, intermediate inputs, final demands, as well as the taxes associated with these transactions. We therefore maintain the 1975 structure of each economy in terms of production and consumption patterns, while allowing gross trade patterns and key budgetary expenditures (especially on the CAP) to change. The database is then re-balanced relative to these new values, ensuring microconsistency in each year.

We want to emphasize that we do not view these updating procedures as definitive or foolproof. To the extent that better data become available we plan to use it, bearing in mind budget constraints on that effort (to date, we have restricted our attention to databases that are freely available in published form).

A more important qualification is that we do not claim that our time series of microconsistent databases satisfies any behavioural or market-based intertemporal consistency requirements. We have a series of databases for different years that satisfy a number of consistency requirements for that particular year. We intend to use this series to construct a series of static GE models, with the model for 1980 using the database for 1980, for example. It is well beyond the scope of the present exercise to deal with dynamic or explicitly intertemporal issues, although we do view the present database as a necessary precursor to the exploration of these issues. 


\section{USING THE DATABASE TO BENCHMARK A STATIC GENERAL-EQUILIBRIUM TRADE MODEL}

Although our data set has been collected for a specific model, it has been our intention that the data be "model independent" in the sense that it could be employed to parameterize any number of model structures. This section shows how it can be used to calibrate a simple, static, multi-regional trade model. Like our EC model, this model uses the Armington assumption (that is, commodities distinguished by region of origin) to explain intra-industry trade. Further, we presume that all producers behave as perfectly competitive price takers. For transparency, this "generic trade model" omits structural details of the European Community, such as the Common Agricultural Program.

\subsection{Structure of a Simple General-Equilibrium Trade Model}

General features of the model used to illustrate our database are listed below. $n$ commodities (indexed by $h$ and $i$ ) are produced in $m$ regions (indexed by $j$ and $l$ ) using the services of three primary factors (land, labor, and capital, indexed by $k$ ) and intermediate commodity inputs in constant-returns, nested-CES production functions. The primary factors are in fixed supply and are mobile between sectors but not between regions. (As described above, land enters only into the agricultural sector's production function.) Let the endowment

of factor $k$ in region $j$ be $E_{k j}$ Goods are distinguished by region of origin. Each region contains a single representative agent with homothetic preferences defined over commodities. No distinction is made between the import composition of final and intermediate demand nor between the investment and consumption components of final demand.

Three commercial policy instruments are used by the regions:

$t_{i j l} \quad$ Discriminatory import tariffs on good $i$ from region $l$ imposed by region $j$, with revenues returned lump-sum to consumers of the importing country.

$s_{i j} \quad$ Proportional subsidy on production of good $i$ in region $j$. 
$v_{k j} \quad$ Value-added tax on production input of primary factor $k$ in region $j$, reflecting the differences between producer cost and market value of factor inputs.

Equilibrium in this model is characterized by the following "central" variables:

$Y_{i j} \quad$ Production of commodity $i$ in region $j$.

$S_{i j} \quad$ Aggregate supply (domestic plus imports) of commodity $i$ in region $j$.

$\pi_{i j} \quad$ Commodity price, good $i$ produced in region $j$.

$p_{i j} \quad$ Commodity price, good $i$ consumed in region $j$.

$w_{k j} \quad$ Factor price, factor $k$ in region $j$.

These variables, in turn, determine price-responsive demands of producers, importers and consumers. These include:

$A_{h i j} \quad$ Intermediate inputs of commodity $h$ in commodity $i$ production in region $j$.

$B_{k i j} \quad$ Inputs of primary factor $k$ in commodity $i$ production in region $j$.

$C_{i j} \quad$ Final consumption demand for commodity $i$ in region $j$.

$M_{i j l} \quad$ Imports of commodity $i$ to region $j$ from region $l$. $\quad\left(M_{i j j}\right.$ represents domestic supplies of commodity $i$ by producers in region $j$ ).

Demand functions are determined through solution of individual subproblems in which producers and importers minimize cost and consumers maximize utility. For example, input demands $A$ and $B$ follow from cost-minimization. For the manufacture of good $i$ in region $j$ producers choose intermediate input coefficients, $a_{h i j}$, and factor input coefficients, $b_{k i j}$, which solve:

$$
\begin{gathered}
\operatorname{minimize} \sum_{h} p_{h j} a_{h i j}+\left(1+v_{i j}\right) \sum_{k} w_{k j} b_{k i j} \\
\text { subject to: } \mathrm{f}_{i j}(a, b)=1
\end{gathered}
$$

where $\mathrm{f}_{i j}(\cdot)$ is region $j$ 's production function for commodity $i$. By nature of constant returns to scale, aggregate demands, $A$ and $B$, are the product of activity levels with input coefficients: $A_{h i j}=Y_{i j} a_{h i j}$ and $b_{k i j}=Y_{i j} b_{k i j}$ 
Import demands arise from the choice of cost-minimizing coefficients for an Armington aggregation over varieties from domestic and foreign suppliers. The import share coefficients solve the following subproblem:

$$
\begin{gathered}
\operatorname{minimize} \sum_{k}\left(1+t_{i j l}\right) \pi_{i l} m_{i j l} \\
\text { subject to: } \mathrm{g}_{i j}(m)=1
\end{gathered}
$$

The import aggregation function $\left(\mathrm{g}_{i j}: \mathbb{R}^{m} \rightarrow \mathbb{R}\right)$ summarizes the composition of commodities from different sources in investment, consumption and intermediate uses. Assuming homothetic preferences, the aggregate supply of good $i$ from region $k$ in region $j$ is then given by $M_{i j l}=S_{i j} m_{i j l}$

Final consumption demands arise from welfare maximization subject to a budget constraint:

$$
\begin{gathered}
\operatorname{maximize} U_{j}(C) \\
\text { subject to: } \sum_{i} \pi_{i j} C_{i j} \leq \sum_{k} w_{k j} E_{k j}+T_{j}+\delta_{j}
\end{gathered}
$$

The budget constraint includes factor earnings, tax revenue and foreign borrowing. The second of these represents income from import tariffs, production subsidies and value-added taxes:

$$
T_{j}=\sum_{i}\left[\sum_{k} t_{i j l} \pi_{i l} M_{i j l}-s_{i j} \pi_{i j} Y_{i j}+v_{i j} \sum_{k} w_{k j} B_{k i j}\right]
$$

$\delta_{j}$ is the value of net capital inflows, represented in a static setting as a lump-sum transfer. Global consistency implies that $\sum_{j} \delta_{j}=0$.

\subsection{Equilibrium Conditions}

A general equilibrium is defined by a set of commodity prices, factor prices and activity levels for which:

(a) Supply is greater or equal to demand in all goods and factor markets. 
(b) The (tax-inclusive) value of outputs is less than or equal to the (tax-inclusive) cost of inputs for all production sectors.

(c) The value of final demand equals the value of factor earnings and tax revenue.

In the present context, these conditions correspond to the following inequalities:

$\begin{array}{lll}\left.\text { (a. } \pi_{i j}\right) & \text { Output markets: } & Y_{i j} \geq \sum_{l} M_{i l j} \\ \left.\text { (a. } p_{i j}\right) & \text { Input markets: } & S_{i j} \geq \sum_{h} A_{i h j}+C_{i j} \\ \text { (a.w } w_{k j} \text { ) } & \text { Factor markets: } & E_{k j} \geq \sum_{i} B_{k i j} \\ \left.\text { (b. } Y_{i j}\right) & \text { Production: } & \left(1+s_{i j} \text { ) } \pi_{i j} Y_{i j} \leq \sum_{h} p_{h j} A_{h i j}+\left(1+v_{i j}\right) \sum_{k} w_{k j} B_{k i j}\right. \\ \left.\text { (b. } S_{i j}\right) & \text { Imports: } & p_{i j} S_{i j} \geq \sum_{l}\left(1+t_{i j l}\right) \pi_{i l} M_{i j l} \\ \text { (c.j) } & \text { Income: } & \sum_{i} p_{i j} C_{i j} \leq \sum_{k} w_{k j} E_{k j}+T_{j}+\delta_{j}\end{array}$

Given the underlying functions $\left(f_{i j}, g_{i j}\right.$ and $\left.U_{j}\right)$, factor endowments $\left(E_{k j}\right)$, and various tax rates $\left(t_{i k j}, v_{i j}\right.$ and $\left.s_{i j}\right)$, a static equilibrium consists of prices and activity levels which satisfy conditions (a) through (c). The nature of the modeling excercise concerns investigating the effect of changes in policy parameters or endowments on the nature of the equilibrium trade, production and welfare patterns. These equilibria can be obtained using a fixed-point algorithm, such as that developed by Broadie (1983), or they may be formulated and solved with a higher-level modeling language such as GAMS [see Brooke, Kendrick, and Meeraus (1988)] or MPS/GE [see Rutherford (1988b)]. The remainder of this section outlines one approach through which the functions $\left(f_{i j}, g_{i j}\right.$, and $\left.U_{j}\right)$ may be parameterized from a representative equilibrium. 


\subsection{Database Contents}

The database provides entries for a sequence of years, 1975 through 1985 . Our calibration procedure applies for any representative year in the sequence and does not impose intertemporal consistency. [This section provides a schematic description of the database and its application. For a more detailed description of the data and software, a technical appendix is available on request from the authors.]

A typical benchmark data file provides the following data for each region: the value of output of each commodity at domestic prices, net of subsidy; the value of that region's imports of each commodity from each of the other regions at international prices, net of tariff payments; payments to intermediate inputs of commodities in each sector at domestic prices; the share of value added paid to primary factor $k$ in sector $i\left(f_{k i j}\right)$; the current-account deficit; the ad-valorem import tariff rate on imports of each commodity from each of the other regions; the proportional subsidy rates on production of commodities; and the value-added tax rate.

Minimal consistency conditions which are satisfied by the benchmark data include:

(i) Net exports reflect balance of payments transfers:

$$
\delta_{j}=\sum_{i l} \sum_{i l}\left(\pi_{i j l}-\pi_{i j} M_{i l j}\right)
$$

(ii) Domestic output exceeds exports:

$$
Y_{i j} \geq \sum_{l} M_{i l j}
$$

(In preparing the benchmark data file, condition (i) is achieved by scaling exports so that the independent balance of payments totals $\left(\delta_{j}\right)$ are obtained. After scaling, (ii) is then checked and, as necessary, domestic outputs are adjusted upward so that exports represent no more than $70 \%$ of domestic output in any country.) .

We emphasize that the benchmark data is relatively compact because of simplifying assumptions which we have incorporated into the model formulation, such as: final demands in each country arise from a single representative agent; the composition of consumption and 
investment demand is identical; and the import composition of intermediate and final demand is identical. Relaxation of any of these assumptions would result in additional data requirements.

\subsection{Calibration}

This final section outlines the steps through which the database entries and elasticity parameters can be used to calibrate our simplified general equilibrium trade model. The basic scheme is first to determine the value of benchmark payments then to use these values (together with assumed functional forms and elasticity parameters) to impute function parameters. This approach is antithetical to econometric estimation. Calibration's principal defense is that it is easily implemented and it provides a reference equilibrium which "resembles" published national accounts.

An important shortcoming of the calibration approach relates to capital markets. Here we assume that rates of return are equalized across sectors in the benchmark year. This simplifying assumption implies that all-factor markets clear and capital stocks are fully adjusted to prevailing output prices, tax rates, and wages. Such assumptions are in sharp contrast to "vintage" formulations of capital in which there could be differences between exante and ex-post malleability, the least of which would tie physical capital to the sector of installation and result in differences in subsequent annual rates of return.

We scale quantities so that benchmark prices for goods and factors are all one. Output levels and endowment quantities therefore represent the value of payments in the benchmark equilibrium. For this reason, and through the assumed homogeneity of import composition for intermediate and final demand, domestic "supplies" of commodity $i$ are given by:

$$
S_{i j}=Y_{i j}+\sum_{l}\left(1+t_{i j l}\right) M_{i j l}-\sum_{l} M_{i l j}
$$

$S_{i j}$ thus represents the value of domestic production and imports, less the cost of exports.

Sector $i$ value added, $V A_{i j}$, may be computed as a residual given the value of output, the subsidy rate, the cost of intermediate inputs, and the value-added tax rate: 


$$
V A_{i j}=\frac{1}{\left(1+v_{i j}\right)}\left[\frac{1}{\left(1-s_{i j}\right)}-\sum_{h} A_{h i j}\right]
$$

Factor inputs are determined by value shares (at prices equal to unity):

$$
B_{k i j}=V A_{i j} f_{k i j}
$$

and, assuming market clearance, factor endowments are set equal to factor demand:

$$
E_{k j}=\sum_{i} B_{k i j}
$$

Aggregate final demand, $C_{i j}$, is the value of domestic supply less intermediate demand for commodity $i$ in region $j$ :

$$
C_{i j}=S_{i j}-\sum_{h} A_{i h j}
$$

This residual calculation is possible by the assumption of a single, representative domestic household.

At this point, we have determined benchmark values for the central variables, intermediate and final demands. The final stage of the calibration involves three steps:

(i) Adopt specific functional forms for production, import aggregation and utility functions: $\mathrm{f}_{i j}(\cdot), \mathrm{g}_{i j}(\cdot)$ and $\mathrm{U}_{j}(\cdot)$ respectively.

(ii) Fix all "free" parameters in these functions (i.e. specify Allen elasticities of substitution - based on independent econometric estimation).

(iii) Based on benchmark inputs, prices and taxes rates, invert the demand functions to determine the "dependent" scale parameters.

We will illustrate these steps using the import aggregation functions, $g_{i j}$ For these functions, we have assumed particular nested CES forms in which there is a distinction between the elasticity of substitution for domestic and imported varieties $\left(\sigma_{D}\right)$ and that which applies to imports from different suppliers $\left(\sigma_{M}\right)$. (To simplify notation, the $i j$ subscripts are omitted from function coefficients.) At the top level, domestic inputs trade off with an 
aggregate of imports; while at the second level imports from different foreign suppliers substitute one for another. When $\sigma_{D}=\sigma_{M}$, this reduces to a single-level CES function. The algebraic form is:

$$
g_{i j}(M)=\left[\alpha_{0} M_{i j j}^{\rho}+\alpha_{1}\left(\sum_{l \neq j} \beta_{l} M_{i j l}^{\gamma}\right)^{\rho / \gamma}\right]^{1 / \rho}
$$

In this function, $\rho$ and $\gamma$ are determined by the elasticities of substitution: $\rho \equiv\left(\sigma_{D}-1\right) / \sigma_{D}$ and $\gamma \equiv\left(\sigma_{M^{-1}}\right) / \sigma_{M^{*}}$

Closed-form import demand functions correspond to solutions of the importer's cost minimization problem. These are given by the:

$$
M_{i j j}=S_{i j}\left\{\frac{\alpha_{0} \mathrm{C}(\pi, t)}{\pi_{i j}}\right\}^{\sigma_{\mathrm{D}}} \cdot \text { and } M_{i j l}=\bar{M}_{i j}\left\{\frac{\beta_{l} c_{\mathrm{M}}}{\pi_{i l}\left(1+t_{i j l}\right)}\right\}^{\sigma_{\mathrm{M}}}
$$

in which:

$$
\begin{aligned}
c_{\mathrm{M}} & =\left\{\sum_{l \neq j} \beta_{l}^{\sigma_{\mathrm{M}}}\left\{\pi_{i l}\left(1+t_{i j l}\right)\right\}^{1-\sigma_{\mathrm{M}}}\right\}^{1 /\left(1-\sigma_{\mathrm{M}}\right)} \text { is the import cost index, } \\
\mathrm{C}(\pi, t) & =\left\{\alpha_{0}^{\sigma_{\mathrm{D}}} \pi_{i j}^{1-\sigma_{\mathrm{D}}}+\alpha_{1}{ }^{\sigma_{\mathrm{D}}} c_{\mathrm{M}}^{1-\sigma_{\mathrm{D}}}\right\}^{1 /\left(1-\sigma_{\mathrm{D}}\right)} \text { is the aggregate cost index, } \\
\text { and } \quad \bar{M}_{i j} & =S_{i j}\left\{\frac{\alpha_{1} \mathrm{C}(\pi, t)}{c_{\mathrm{M}}}\right\}^{\sigma_{\mathrm{D}}} \text { is the import quantity index. }
\end{aligned}
$$

The import price index, $c_{\mathrm{M}}$, and the import demand functions reflect discriminatory import tariffs, $t_{i j l}$

In the benchmark equilibrium, all output prices are unity; $\alpha_{1}$ can be selected so that $c_{M}$ is also one; $\mathrm{C}(\pi, t)$ is equal to the value of output, $S_{i j}$; and $\bar{M}_{i j}=\sum_{l \neq j}\left(1+t_{i j l}\right) M_{i j l}$ Given elasticities and cost shares, we then determine parameters $\alpha$ and $\beta$ by inverting the demand functions, (with the implicit assumption that import activities are fully adjusted to benchmark prices). Some algebraic manipulation provides: 


$$
\alpha_{0}=\frac{M_{i j j}{ }^{1 / \sigma_{\mathrm{D}}}}{\mathrm{C}(\pi, t)}, \alpha_{1}=\frac{\bar{M}_{i j}{ }^{1 / \sigma_{\mathrm{D}}}}{\mathrm{C}(\pi, t)}, \quad \text { and } \quad \beta_{k}=\frac{\left(1+t_{i j l}\right) M_{i j l}{ }^{1 / \sigma_{\mathrm{M}}}}{\bar{M}_{i j}} \text {. }
$$

Similar calculations are used to determine parameters for the production technologies and preferences. In our EC model, the nesting structures are themselves input parameters. This is possible without extensive programming effort because the model is benchmarked and solved using MPS/GE in which arbitrary nested CES functions can be specified. 
TABLE 1

PRODUCTION SECTORS IN EC DATABASE

EC

EC

ID Description

Branch Sub-Branch

1. Agricultural, Forestry, \& Fishery Products 010

2. Coal, Lignite, \& Briquettes 030

3. Products of Coking 050

4. Crude Petroleum, Natural Gas \& Petroleum 070

5. Electric Power, Gas, Steam \& Water 090 Electric Power, Steam, Hot Water, etc. 091

$\begin{array}{ll}\text { Gas Distributed by Pipes } & 092\end{array}$

Water

095

6. Production \& Processing of Radioactive Materials $\quad 110$

7. Other Ferrous \& Non-Ferrous Ores \& Metals 130

Ferrous Metals \& Minerals Non-Ferrous Metals \& Minerals

8. Non-Metallic Mineral Products 150

9. Chemical Products 170

10. Metal Products except Mach.\& Transp. 190

Equipment

11. Agricultural and Industrial Machinery 210

12. Office \& Data-Processing Machines 230

\& Instruments

13. Electrical Goods 250

14. Motor Vehicles 270

15. Other Transport Equipment 290

16. Meats and Meat Products $\quad 310$

17. Milk and Dairy Products 330

18. Other Food Products 350

19. Beverages 370

20. Tobacco Products 390

21. Textiles and Clothing 410

22. Leather Goods and Footwear 430

23. Timber, Wood Products and Furniture 450

24. Paper and Printing Products 470

25. Rubber and Plastic Products 490

26. Other Manufacturing Products 510

27. Building and Construction 530

28. Recovery and Repair Services 550

29. Wholesale and Retail Trade 570

30. Lodging and Catering Services $\quad 590$

31. Inland Transportation Services 610

32. Maritime and Air Transport Services 630 Maritime Transport and Coastal Services $\quad 631$

Air Transport Services

33. Auxiliary Transport Services 650

34. Communication Services 670 
35. Services of Credit and Insurance

Institutions

36. Business Services provided to Enterprises

37. Services of Renting of Immovable Goods 730

38. Market Services of Education and Research 750

39. Market Services of Health 770

40. Recreational \& Market Services n.e.c. 790

41. General Public Services 810

42. Non-Market Services of Education \& Research 850

43. Non-Market Services of Health 890

44. Domestic Services \& Other Non-Market

Services

930

Total

990

TABLE 2

FINAL USES IN EC DATABASE

\begin{tabular}{|c|c|c|c|}
\hline D & $\begin{array}{l}\text { EC } \\
\text { Code }\end{array}$ & Included? & Description \\
\hline & $\begin{array}{l}01 \\
02 \\
03\end{array}$ & & $\begin{array}{l}\text { Final Consumption of Domestic Households } \\
\text { Collective Consumption of General Government } \\
\text { Collective Consumption of Private Non-profit } \\
\text { Institutions }\end{array}$ \\
\hline 1 & $\begin{array}{l}09 \\
19 \\
29\end{array}$ & * & $\begin{array}{l}\text { Final Consumption of Domestic Agents }(01+02+03) \\
\text { Gross Fixed Capital Formation } \\
\text { Change in Stocks }\end{array}$ \\
\hline 2 & 41 & * & Exports of Goods and Services to EEC Countries \\
\hline 3 & $\begin{array}{l}42 \\
43\end{array}$ & * & $\begin{array}{l}\text { Exports of Goods and Services to Third Countries } \\
\text { Adjustment }\end{array}$ \\
\hline 4 & $\begin{array}{l}49 \\
89\end{array}$ & * & $\begin{array}{l}\text { Total Exports of Goods and Services }(41+42+43) \\
\text { Final Uses }(09+19+29+49)\end{array}$ \\
\hline 5 & 99 & * & Total Uses $(89+$ Total Intermediate Uses) \\
\hline
\end{tabular}


TABLE 3

PRIMARY INPUTS IN EC DATABASE

ID $\stackrel{\text { EC }}{\text { Code }}$ Description

\begin{tabular}{rll}
\hline \hline & & \\
1 & 010 & Gross Wages \& Salaries \\
2 & 020 & Employers' Social Contributions \\
3 & 030 & Net Operating Surplus \\
4 & 070 & Net Value Added at Factor Cost \\
5 & 080 & Consumption of Fixed Capital \\
6 & 090 & Gross Value Added at Factor Cost \\
7 & 110 & Taxes Linked to Production (excluding VAT) \\
8 & 120 & Subsidies \\
9 & 170 & Net Taxes Linked to Production (excluding VAT) \\
10 & 180 & Net Value Added at Market Prices \\
11 & 190 & Gross Value Added at Market Prices \\
12 & 290 & Actual Output at Producers Prices \\
13 & 310 & Transfers of Ordinary By-Products at Approximate Factor Prices \\
14 & 330 & Transfers of Incidental Sales at Approximate Factor Prices \\
15 & 390 & Total Transfers at Approximate Factor Prices \\
16 & 410 & Subsidies Linked to Exports \\
17 & 490 & Distributed Output at Producers Prices \\
18 & 510 & Imports c.i.f. of Similar Products from EEC Countries \\
19 & 520 & Imports c.i.f. of Similar products from Third Countries \\
20 & 590 & Total Imports c.if. of Similar Products \\
21 & 610 & Taxes Linked to Imports of Similar Products from EEC Countries \\
22 & 620 & (excl. VAT) \\
& Taxes Linked to Imports of Similar Products from Third Countries \\
23 & 690 & (excl. VAT) \\
24 & 710 & Total Taxes Linked to Imports of Similar Products (excl. VAT) \\
25 & 720 & Imports of Similar Products from EEC Countries at Ex-Customs Prices \\
26 & 790 & Imports of Similar Products from Third Countries at Ex-Customs Prices \\
27 & 870 & Total Imports of Similar Products at Ex-Customs Prices \\
28 & 980 & VAT Imposed on Domestic and Imported Products \\
\hline \hline & & Total Resources \\
\hline
\end{tabular}


TABLE 4

Structure of Individual Country Data File

\begin{tabular}{|c|c|c|}
\hline Rows & \# Cols. & Description \\
\hline 1 & 45 & Total Intermediate Inputs (domestic) \\
\hline 52 & 1 & Total Intermediate Outlays (domestic) \\
\hline 1 & 45 & Total Intermediate Inputs (imports) \\
\hline 52 & 1 & Total Intermediate Outlays (imports) \\
\hline 1 & 12 & Totals for each Final Demand Item (domestic) \\
\hline 52 & 1 & Final Demand by Domestic Residents (domestic) \\
\hline 52 & 1 & Final Demand by.Other EEC Countries (domestic) \\
\hline 52 & 1 & Final Demand by Third Countries (domestic) \\
\hline 52 & 1 & Total Final Demand (domestic) \\
\hline 52 & 1 & Total Uses (domestic) \\
\hline 1 & 12 & Totals for each Final Demand Item (imported) \\
\hline 52 & 1 & Final Demand by Domestic Residents (imported) \\
\hline 52 & 1 & Final Demand by Other EEC Countries (imported) \\
\hline 52 & 1 & Final Demand by Third Countries (imported) \\
\hline 52 & 1 & Total Final Demand (imported) \\
\hline 52 & 1 & Total Uses (imported) \\
\hline 28 & 45 & Primary Inputs \\
\hline 1 & 44 & Total Intermediate Inputs Imported from EEC \\
\hline 52 & 1 & Total Intermediate Outlays Imported from EEC \\
\hline 52 & 1 & Final Demand by Domestic Residents Imported from EEC \\
\hline 1 & 8 & Totals for Final Demand Items Imported from EEC \\
\hline
\end{tabular}

Notes: Arrays with 45 or 52 columns or rows, respectively, include a control total used to ensure that individual items are correct. 
TABLE 5

ELASTICITIES OF FACTOR SUBSTITUTION

\begin{tabular}{llll} 
Sector Estimated & $\begin{array}{l}\text { EC Sectors } \\
\text { Estimate is } \\
\text { Applied to }\end{array}$ & $\begin{array}{l}\text { Point } \\
\text { Estimate }\end{array}$ & $\begin{array}{l}\text { Standard } \\
\text { Error }\end{array}$ \\
\hline \hline & & & \\
Agriculture and Food & $1,16-20$ & 0.9450 & 0.0407 \\
Mining & $2,3,7$ & 0.4256 & 0.1050 \\
Energy & 4,6 & 0.2930 & 0.1016 \\
Tobacco & 20 & 0.8386 & 0.0893 \\
Textiles & 21 & 0.9266 & 0.0766 \\
Lumber and Wood Products & 23 & 0.7449 & 0.1136 \\
Paper Products & 24 & 1.089 & 0.1078 \\
Chemicals & 9 & 1.009 & 0.0268 \\
Rubber and Plastics & 25 & 0.9717 & 0.0820 \\
Leather Products & 22 & 0.7473 & 0.1647 \\
Stone, Clay and Glass & 8 & 0.9582 & 0.1317 \\
Primary Metals & 10 & 0.9110 & 0.2411 \\
Miscellaneous Manufacturing & 26 & 1.189 & 0.0545 \\
Machinery & $11,14,15$ & 1.202 & 0.0897 \\
Electrical Machines & 13 & 0.9808 & 0.0267 \\
Instruments & 12 & 1.213 & 0.1651 \\
Transportation and Utilities & $31-34,5$ & 1.884 & 0.2489 \\
Wholesale and Retail Trade & 29,30 & 1.283 & 0.525 \\
Finance & 35,36 & 2.055 & 0.255 \\
Services & $38-40$ & 3.125 & 0.817 \\
Other Non-Traded & $27,28,37,41-44$ & 1.988 & 0.477 \\
& & & \\
\hline
\end{tabular}


TABLE 6

ELASTICITIES OF SUBSTITUTION BETWEEN

DOMESTIC AND IMPORTED GOODS

(a) Sector-specific elasticities

\begin{tabular}{clllllll}
\multicolumn{2}{r}{ Sector ID Elasticity } & \multicolumn{2}{c}{ Sector ID Elasticity } & \multicolumn{2}{c}{ Sector ID Elasticity } \\
\hline \hline 1 & 2.0 & 16 & 0.5 & 31 & 2.0 \\
2 & 0.5 & 17 & 2.0 & 32 & 2.0 \\
3 & 0.5 & 18 & 1.5 & 33 & 2.0 \\
4 & 0.34 & 19 & 2.1 & 34 & 2.0 \\
5 & 2.0 & 20 & 2.0 & 35 & 2.0 \\
6 & 0.34 & 21 & 2.0 & 36 & 2.0 \\
7 & 1.4 & 22 & 6.8 & 37 & 2.0 \\
8 & 1.3 & 23 & 1.9 & 38 & 2.0 \\
9 & 2.0 & 24 & 1.1 & 39 & 2.0 \\
10 & 0.5 & 25 & 0.3 & 40 & 2.0 \\
11 & 0.5 & 26 & 2.0 & 41 & 2.0 \\
12 & 2.0 & 27 & 2.0 & 42 & 2.0 \\
13 & 1.3 & 28 & 2.0 & 43 & 2.0 \\
14 & 5.0 & 29 & 2.0 & & 44 & 2.0 \\
15 & 0.5 & 30 & 2.0 & & &
\end{tabular}

(b) Country-specific elasticities

\begin{tabular}{lll} 
Country & Elasticity & Standard Error \\
\hline \hline Germany & 1.6996 & 0.3969 \\
France & 1.0570 & 0.2358 \\
Italy & 1.1650 & 0.5939 \\
Netherlands & 0.6850 & 0.2823 \\
Belgium & 1.2422 & 0.5801 \\
UK & 0.5293 & 0.1628 \\
Denmark & 0.8845 & 0.2228 \\
Ireland & 0.3380 & 0.2340 \\
ROW & 1.4132 & 0.3412 \\
\hline
\end{tabular}


TABLE 7

COMPARISON OF CONVERSION FACTORS FOR NATIONAL CURRENCY UNITS

Units of National Currency per US Dollar

\begin{tabular}{|c|c|c|c|}
\hline Country & $\begin{array}{l}1975 \\
\text { PPP }\end{array}$ & $\begin{array}{c}1975 \\
\text { Exchange } \\
\text { Rate }\end{array}$ & Ratio \\
\hline Germany & 2.91 & 2.45 & 1.19 \\
\hline France & 4.76 & 4.28 & 1.11 \\
\hline Italy & 572.45 & 625.74 & 0.88 \\
\hline Netherlands & 2.87 & 2.52 & 1.14 \\
\hline Belgium & 41.27 & 36.67 & 1.13 \\
\hline UK & 0.39 & 0.45 & 0.87 \\
\hline Denmark & 7.12 & 5.73 & 1.24 \\
\hline Ireland & 0.39 & 0.45 & 0.86 \\
\hline Japan & 279.99 & 296.82 & 0.94 \\
\hline US & 1.00 & 1.00 & 1.00 \\
\hline
\end{tabular}

Source: Summers and Heston (1988; Appendix database on floppy disk). "PPP" is their variable 13 expressed in absolute value, and "Exchange Rate" is their variable 17. 
TABLE 8

PRODUCTION SECTORS IN PACIFIC BASIN DATABASE

ID Description

\begin{tabular}{ll}
\hline 1 & Paddy \\
2 & Other Agriculture \\
3 & Livestock \\
4 & Forestry \\
5 & Fishery \\
6 & Crude Petroleum and Natural Gas \\
7 & Other Mining \\
8 & Food, Beverage and Tobacco \\
10 & Textile and Leather Products \\
11 & Lumber and Wood Products \\
12 & Pulp, Paper and Printing \\
13 & Chemical Products \\
14 & Petroleum Products \\
15 & Rubber Products \\
16 & Non-metallic Mineral Products \\
17 & Metal Products \\
18 & Machinery \\
19 & Transport Equipment \\
20 & Other Manufacturing \\
21 & Electricity, Gas and Water Supply \\
22 & Construction \\
23 & Trade and Transport \\
24 & Services \\
& Public Administration \\
\hline \hline
\end{tabular}


TABLE 9

EC BUDGET: SOURCE OF REVENUES

All values in billions of EUA (1973-1977) or ECU (1978-1985)

\begin{tabular}{lccccc} 
Year & $\begin{array}{c}\text { Customs } \\
\text { Duties }\end{array}$ & $\begin{array}{c}\text { Import } \\
\text { and Sugar } \\
\text { Levies }\end{array}$ & VAT & $\begin{array}{c}\text { Percent } \\
\text { VAT } \\
\text { Rate }\end{array}$ & Total \\
\hline \hline & & & & & \\
1973 & 1.94 & 0.55 & 2.09 & - & 4.58 \\
1974 & 2.74 & 0.33 & 1.90 & - & 4.97 \\
1975 & 3.15 & 0.59 & 2.15 & - & 5.89 \\
1976 & 4.19 & 1.17 & 2.49 & - & 7.85 \\
1977 & 4.46 & 2.14 & 2.56 & - & 9.15 \\
1978 & 4.39 & 2.28 & 5.33 & 0.64 & 12.00 \\
1979 & 5.19 & 2.14 & 7.04 & 0.79 & 14.37 \\
1980 & 5.91 & 2.00 & 7.26 & 0.73 & 15.17 \\
1981 & 6.39 & 1.75 & 9.19 & 0.79 & 17.48 \\
1982 & 6.81 & 2.23 & 12.00 & 0.92 & 21.24 \\
1983 & 6.99 & 2.30 & 13.70 & 1.00 & 23.20 \\
1984 & 7.96 & 2.44 & 14.37 & 1.00 & 25.99 \\
1985 & 8.31 & 2.18 & 15.22 & 1.00 & 27.94 \\
& & & & & \\
\hline \hline
\end{tabular}

Notes: (1) The Percent VAT Rate is the "uniform rate, before corrections to temper budgetary disequilibria".

(2) Total revenues include "Financial Contributions" and "Additional Financing" in applicable years.

(3) Data for 1975-1981 refer to EUR 9, and for 1982-1985 to EUR 10.

Source: EEC, The Agricultural Situation in the Community, various Annual Reports (1976-1985 data); Statistical Office of the EC, Eurostat Review 1971-80, 1982 (1973-1975 data). 
TABLE 10

EC BUDGET: SHARE OF REVENUES

Total Revenues expressed in billions of

EUA (1973-1977) or ECU (1978-1980)

Percentage of Total

Total
Year
Revenues

Germany France Italy Netherlands Belgium UK Denmark Ireland

\begin{tabular}{lrrrrrrrrr}
\hline \hline & & & & & & & & & \\
1973 & 4.584 & 29.0 & 24.8 & 19.0 & 9.4 & 7.4 & 8.8 & 1.1 & 0.3 \\
1974 & 4.972 & 28.5 & 24.0 & 18.4 & 9.1 & 7.1 & 11.0 & 1.4 & 0.3 \\
1975 & 5.893 & 28.1 & 22.8 & 17.5 & 9.0 & 6.7 & 13.6 & 1.7 & 0.4 \\
1976 & 7.710 & 27.3 & 21.4 & 17.1 & 8.8 & 6.5 & 16.2 & 2.1 & 0.5 \\
1977 & 8.200 & 25.8 & 20.3 & 16.7 & 8.6 & 6.3 & 19.2 & 2.4 & 0.6 \\
1978 & 12.004 & 29.4 & 18.2 & 13.8 & 9.9 & 6.2 & 19.4 & 2.3 & 0.7 \\
1979 & 14.372 & 29.5 & 19.0 & 11.8 & 9.0 & 6.4 & 21.1 & 2.4 & 0.7 \\
1980 & 15.263 & 29.6 & 19.2 & 12.6 & 8.3 & 6.2 & 20.8 & 2.3 & 0.9 \\
\multirow{2}{*}{ Average } & - & 28.4 & 21.2 & 15.9 & 9.0 & 6.6 & 16.3 & 2.0 & 0.6 \\
\hline
\end{tabular}

Source: $\quad$ Statistical Office of the EC, Eurostat Review 1971-1980, 1982.

TABLE 11

EC BUDGET: SHARE OF EXPENDITURES

Total Expenditures expressed in billions of EUA (1976-1977) or ECU (1978-1980)

Total

Year Expenditure

Germany France Italy Netherlands Belgium UK Denmark Ireland

\begin{tabular}{lrrrrrrrrr}
\hline \hline & & & & & & & & & \\
1976 & 6.579 & 16.5 & 23.5 & 17.4 & 11.9 & 5.9 & 15.1 & 6.1 & 3.5 \\
1977 & 7.817 & 17.6 & 19.7 & 15.2 & 10.5 & 5.8 & 19.1 & 6.0 & 6.0 \\
1978 & 10.804 & 25.1 & 15.7 & 18.6 & 11.3 & 6.0 & 13.7 & 5.6 & 3.8 \\
1979 & 12.847 & 21.4 & 20.6 & 16.9 & 12.0 & 6.6 & 12.6 & 5.5 & 4.9 \\
1980 & 14.592 & 20.1 & 23.1 & 17.9 & 11.4 & 4.6 & 12.4 & 4.7 & 5.7 \\
\multirow{2}{*}{ Average } & - & 20.1 & 20.5 & 17.2 & 11.4 & 5.8 & 14.6 & 5.6 & 4.8 \\
\hline
\end{tabular}

Source: - Statistical Office of the EC, Eurostat Review 1971-1980, 1982. 


\section{REFERENCES}

Ballard, Charles L., Fullerton, Don, Shoven, John B., and Whalley, John, A General Equilibrium Model for Tax Policy Evaluation, Chicago: University of Chicago Press, 1985.

Barker, Terry, van der Ploeg, Frederick, and Weale, Martin, "A Balanced System of National Accounts for the United Kingdom," The Review of Income and Wealth, December 1984, $30,461-485$.

Broadie, M.N., "OCTASOLV User's Guide," Technical Report, Department of Operations Research, Stanford University, 1983.

Brooke, A., Kendrick, D., and Meeraus, A., GAMS: A User's Guide, Redwood City, California: The Scientific Press, 1988.

Commission of the European Communities, The Agricultural Situation in the Community: 1986 Report, Luxembourg: Office for Official Publications of the European Communities, 1987.

Conference of European Statisticians, Standardized Input-Output Tables of ECE Countries for Years Around 1959, United Nations Statistical Standards and Studies No. 25, New York, 1972.

Standardized Input-Output Tables of ECE Countries for Years Around 1965, United Nations Statistical Standards and Studies No. 30, New York, 1977.

Standardized Input-Output Tables of ECE Countries for Years Around 1975, United Nations Statistical Standards and Studies No. 34, New York, 1982.

Dixon, Peter B., Parmenter, B.R., Sutton, John, and Vincent, D.P., ORANI: A Multisectoral Model of the Australian Economy, Amsterdam: North-Holland, 1982.

General Agreement on Tariffs and Trade, International Trade 1986-87, Geneva: GATT, 1987.

Harrison, Glenn W., "A General Equilibrium Analysis of Tariff Reductions," in T.N. Srinivasan and J. Whalley (eds.), General Equilibrium Trade Policy Modelling, Boston: MIT Press, 1986.

, Jones, Richard, Kimbell, Larry J., and Wigle, Randall, "How Robust Is Applied General Equilibrium Analysis?" CSIER Working Paper No. 8707C, University of Western Ontario, May 1987.

, Rutherford, Thomas F., and Wooton, Ian, (1989a) "The Economic Impact of the European Community," American Economic Review 79, May 1989, forthcoming.

Agricultural Policy of the European Communities," mimeo., Department of Economics, University of Western Ontario, 1989.

Higgs, Peter J., "The IDE ASEAN-Korea-US-Japan Input-Output Data Base", Preliminary Working Paper No. IP-22, IMPACT Project, University of Melbourne, June 1985. 
Institute of Developing Economies, International Input-Output Table Japan-U.S.A. 1970, IDE Statistical Data Series No. 24, Tokyo, 1977. 30, Tokyo, March 1980.

Basic Input-Output Table of Thailand 1975, IDE Statistical Data Series No. (1981a) International Input-Output Table Indonesia-Japan 1975, IDE Statistical Data Series No. 33, Tokyo, March 1981.

, (1981b) International Input-Output Table Japan-Korea 1975, IDE Statistical Data Series No. 34, Tokyo, March 1981.

(1981c) International Input-Output Table Thailand-Japan 1975, IDE Statistical Data Series No. 35, Tokyo, October 1981.

(1982a) Input-Output Table Peninsular Malaysia 1975, IDE Statistical Data Series No. 37, Tokyo, March 1982.

38, Tokyo, March 1982.

, (1982b) Input-Output Table Singapore 1975, IDE Statistical Data Series No. (1982c) International Input-Output Table for ASEAN Countries 1975, IDE Statistical Data Series No. 39, Tokyó, 1982.

Kravis, I.B., Heston, A, Kenessy, Z, and Summers, R., A System of International Comparisons of Gross Product and Purchasing Power, Washington, D.C.: Johns Hopkins Press, 1975.

Piggott, John; and Whalley, John, UK Tax Policy and Applied General Equilibrium Analysis, Cambridge: Cambridge University Press, 1985.

Roman, Jean-Claude, "Treatment of Subsidies in National Accounts," The Review of Income and Wealth, March 1985, 31, 39-61.

Roningen, V., and Yeats, A.J., "Non-Tariff Distortions of International Trade: Some Preliminary Empirical Evidence," Weltwirtschaftliches Archiv, 1976, 112, 613-625.

Rutherford, Thomas F., (1988a) "Notes on the PC Diskette Version of the IBRD 1987 World Tables," mimeo. Department of Economics, University of Western Ontario, 1988.

Rutherford, Thomas F., (1988b) "General Equilibrium Modeling with MPS/GE," mimeo., Department of Economics, University of Western Ontario, 1988.

Spencer, J.E., (1985a) "The European Economic Community: General Equilibrium Computations and the Economic Implications of Membership," in J. Piggott and J. Whalley (eds.), New Developments in Applied General Equilibrium Analysis, Cambridge: Cambridge University Press, 1985. Ulster at Coleraine, 1985. 
Statistical Office of the European Communities, (1981a) Five-Yearly Input-Output Table: Denmark-1975, Luxembourg: Eurostat, January 1981.

(1981b) Five-Yearly Input-Output Table: Nederland-1975, Luxembourg: Eurostat, February 1981.

May 1981.

, (1981c) Five-Yearly Input-Output Table: Italia-1975, Luxembourg: Eurostat,

(1981d) Five-Yearly Input-Output Table: United Kingdom-1975, Luxembourg: Eurostat, September 1981.

Eurostat, January 1982.

Luxembourg: Eurostat, March 1982.

Eurostat, 1982.

(1982c) Five-Yearly Input-Output Table: Belgique-1975, Luxembourg:

, National Accounts ESA: Input-Output Tables 1975, Luxembourg: Eurostat, 1983.

1987.

Stone, J.R.N., Champernowne, D.G., and Meade, J.E., "The Precision of National Income Estimates," Review of Economic Studies, 1942, 9, 111-125.

Summers, Robert, and Heston, Alan, "A New Set of International Comparisons of Real Product and Price Levels Estimates for 130 Countries, 1950-1985," The Review of Income and Wealth, March 1988, 34, 1-25.

van Tongeren, Jan W., "Development of an Algorithm for the Compilation of National Accounts and Related Systems of Statistics," The Review of Income and Wealth, March $1986,32,25-47$.

Vincent, David P., "Reclassifying Gross Operating Surplus Shares for Primary Industries: 1968/69 Input-Output Tables," ORANI Research Memorandum OA-40, IMPACT Project, University of Melbourne, 1977.

Whalley, John, Trade Liberalization Among Major World Trading Areas, Cambridge: MIT Press, 1985.

World Bank, World Tables: The Third Edition, Baltimore: John Hopkins University Press, 1983.

, "1987 World Tables Tape Documentation," Washington: International Economics Department, World Bank, April 1988. 
34

Yeats, A.J., "Effective Protection for Processed Agricultural Commodities: A Comparison of Industrial Countries," Journal of Economics and Business, Fall 1976, 29, 31-40.

, Trade Barriers Facing Developing Countries: Commercial Policy Measures and Shipping, London: Macmillan, 1979. 